Przegląd Badań Edukacyjnych Educational Studies Review

ISSN 1895-4308

nr 25 (2/2017), s. 183-200
ORYGINALNE ARTYKULY BADAWCZE

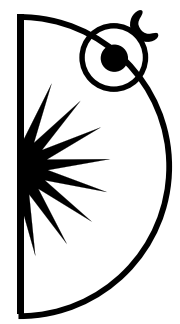

Renata Szczepanik

Uniwersytet Łódzki, e-mail: szczepanik@uni.lodz.pl

\title{
Zarządzanie relacjami z partnerkami życiowymi przez mężczyzn odbywających karę pozbawienia wolności. Badania biograficzne z udziałem recydywistów
}

DOI: http://dx.doi.org/10.12775/PBE.2017.026

\section{How Do Men in Prison Manage Relationship with Their Female Partners? A Biographical Study of Repeat Offenders}

\begin{abstract}
:
The aim of this paper is to analyze the ways in which men in prison manage their relationships with female partners. Drawing on the theoretical perspective of dramaturgy and grounded theory methodology, the article presents an analysis of interviews with habitual offenders. The ways in which these offenders manage relationships with women are considered within a broader strategy of achieving a desired status among other inmates. The focus of the study is not on the interactions between men in prison and their female partners, but the interactions among men in prison. Specifically, the article identifies three interaction strategies for managing the relations with women - giving permission, breaking up and setting free. Each of these strategies encapsulates patriarchal values that the offender defends.
\end{abstract}

Key words: prison, inmates' relationships with female partners, strategy of achieving a desired status among other inmates, dramaturgy 


\section{Wprowadzenie}

Cechy więzienia jako instytucji totalnej oraz konsekwencje dla funkcjonowania człowieka są dobrze opisane w piśmiennictwie naukowym przedmiotu. Na panujący w instytucji więziennej klimat składa się wiele elementów, które współtworzą warunki bezwzględnej izolacji człowieka, obejmując jego sferę fizyczną, psychiczną i społeczną (Goffman 2011; Ciosek 1995; Moczydłowski 1988). Intencjonalnie tworzona architektura przestrzeni i organizacja miejsca (Ambrozik 2013; Chomczyński 2013, Szczepanik 2015) ostatecznie konstytuuje procesy stygmatyzacji, standaryzacji, degradacji oraz depersonalizacji. Izolacyjna funkcja zakładów karnych spełniana jest poprzez naruszanie autonomii więźnia, znaczące zakłócenie dotychczasowych kontaktów i więzi społecznych, a także pozbawienie go dostępu do szeregu udogodnień i usług. Poczucie bezpieczeństwa człowieka zostaje zachwiane, a swoboda decydowania o sobie oraz wpływania na wydarzenia związane z życiem swoim i osób bliskich znacząco ograniczone.

Zarysowana powyżej charakterystyka instytucji totalnej stanowi kontekst badań zaprezentowanych $\mathrm{w}$ tym artykule. Bohaterami opracowania są bowiem przestępcy powrotni z doświadczeniem wielu pobytów i wielu lat spędzonych w jednostkach penitencjarnych.

Badania utrzymane są w paradygmacie interpretatywnym, który rozwijany jest $\mathrm{w}$ ramach różnych nurtów interakcyjnych i dyskursywnych, znajdujących swoje empiryczne ugruntowanie w badaniach jakościowych (m. in. Wyka 1993; Hałas 2006). Ontologiczne przesłanki ujmowania doświadczeń życiowych recydywistów zaczerpnęłam z teorii symbolicznego interakcjonizmu. Rzeczywistość społeczna powrotnych przestępców ujawniała się w toku analizy interakcji, w których uczestniczyli mężczyźni, w procesie badania ich sposobów interpretowania i definiowania sytuacji (subiektywnych znaczeń) i wynikających z tego działań (zob. Blumer 2007; Hałas 2006). Pojęcia i relacje opisane w niniejszym artykule zostały wygenerowane $\mathrm{z}$ danych, jakimi były pozyskane przeze mnie biografie mężczyzn z doświadczeniem co najmniej trzykrotnego pobytu w więzieniu. Podstawowy (aczkolwiek niejedyny) materiał empiryczny stanowiły zapisy wywiadów narracyjnych i swobodnych (Szczepanik 2015). Przyjęcie perspektywy poznania wykraczającej poza indywidualne biografie jednostek i dającej warunki odkrywania ogólnych wzorów i mechanizmów kształtujących sens działania podmiotu oraz relacji społecznych, jakie są jego udziałem, umożliwiły mi procedury metodologii teorii ugruntowanej.

Przedmiot zainteresowania prezentowanych $\mathrm{w}$ opracowaniu badań stanowią działania recydywistów zorientowane na kreowanie wizerunku osoby, 
która w warunkach izolacji społecznej kontroluje wydarzenia, wpływa na nie i (co więcej) cechuje ją wysoka skuteczność swoich dążeń. Będzie więc to autoprezentacja osoby, która mimo ograniczeń narzucanych przez instytucję totalną jest aktywnym kreatorem swojej biografii.

Co prawda skupiam tutaj uwagę na relacjach osadzonych mężczyzn z kobietami, jednakże to nie one i nie jakość tych związków stanowi centrum mojego zainteresowania. Celem badań jest ukazanie i analiza taktyk zarządzania przez skazanych relacjami z kobietami, gdzie głównymi adresatami działań nie są one same, ale publiczność do której adresowany jest swoisty przekaz recydywisty, czyli współosadzeni. W istocie więc analizie poddam nie to co się dzieje między kobietami a mężczyznami, ale to, co zachodzi pomiędzy skazanymi mężczyznami.

W artykule wykażę, że zarządzanie relacjami z kobietami pozwala skazanym mężczyznom na wytwarzanie i potwierdzanie wśród współosadzonych wizerunku osoby wpływającej i kontrolującej bieg swojej biografii, a także na odbudowywanie zachwianego (z rozmaitych przyczyn) obrazu kogoś, kto „panuje" nad swoim życiem. Sposoby zarządzania relacjami z kobietami traktuję bowiem jako taktyki wspierające strategie działań na rzecz wzmacniania pożądanej pozycji społecznej w grupie współwięźniów, w warunkach instytucji totalnej ${ }^{1}$.

Problem odzyskiwania czy podtrzymywania poczucia kontroli wydarzeń, zagadnienie skuteczności oraz bycia aktywnym kreatorem swojej biografii w warunkach znaczących ograniczeń, jakie narzuca rygor instytucji totalnej, można oczywiście analizować z punktu widzenia psychologicznych sposobów kompensowania deprywacji powodowanych izolacją społeczną, czy procesów odpowiadających za budowanie sprawczości jednostki uwikłanej w relacje władzy i podporządkowania. W tym artykule proponuję spojrzenie na rzeczone problemy przez pryzmat perspektywy dramaturgicznej. Parafrazując E. Goff-

${ }^{1}$ Szerokim kontekstem analiz prezentowanych w artykule są doświadczenia biograficzne przestępców powrotnych, szczególnie w okresie odbywania kary pozbawienia wolności. Zagadnienie to stanowi przedmiot pogłębionych rozważań w książce pt. Stawanie się recydywistą. Kariery instytucjonalne osób powracających do przestępczości (Szczepanik 2015 ). W biografiach recydywistów kobiety i związki romantyczne z nimi silnie zaznaczyły swoje miejsce oraz znaczenie, zarówno dla procesu wzmacniania, jak i hamowania kariery dewiacyjnej. Zarządzanie relacjami z kobietami jako przestrzeń działań na rzecz kreowania pożądanego wizerunku wśród współosadzonych nie stanowiła odrębnego miejsca refleksji, dlatego też treści przedstawione w opracowaniu traktuję jako uzupełnienie doświadczeń biograficznych recydywistów składających się na przebieg ich karier instytucjonalnych. 
mana (2006, s. 3): interesuje mnie bowiem nie to, co przeżywają ludzie, ale to w czym uczestniczą.

\section{Koncepcja dramaturgiczna jako teoretyczna perspektywa analiz działań recydywistów na rzecz kreowania pożądanego wizerunku w grupie współosadzonych}

W koncepcji dramaturgicznej przedmiotem zainteresowania nie jest jednostka i jej psychiczne stany, lecz reakcje łączące działania osób biorących udział w interakcji. Model dramaturgiczny zakłada, że formą bezpośredniej interakcji jest przedstawienie (swoisty spektakl), w trakcie którego jednostka (lub zespół) prezentuje swoją tożsamość i role aktualnym partnerom. Podstawowe rodzaje pracy z własnym wizerunkiem jednostki polegają między innymi na koncentracji wokół ukrywania swego prawdziwego oblicza, względnie jego korygowania, aby ,jak najlepiej wypaść" przed współobecnymi.

W myśl założeń koncepcji dramaturgicznej jednostka uwikłana jest w mikrospołeczne prawa sceny, na której ciągle musi się poruszać i w obrębie której uzyskuje wpływy na innych jej uczestników. Odbywa się to poprzez tworzone (auto)prezentacje, kontrolę ekspresji własnej i adwersarzy oraz negocjowanie ról społecznych, w których występują interlokutorzy. Zasadniczym polem analiz w modelu dramaturgicznym są zachowania komunikacyjne. Dodatkową cechą tego podejścia jest akcentowanie „gry pozorów”, która występuje w obrębie przelotnych interakcji jednostek.

Koncepcja została zaprezentowana w 1956 roku, w książce pod znamiennym tytułem Człowiek $w$ teatrze życia codziennego, a w latach następnychodpowiednio poszerzana w postaci kolejnych edycji tej publikacji (Jasińska-Kania et.al., 2006; Goffman 2008a, 2008b). E. Goffmana interesuje ta kategoria zdarzeń, która powstaje podczas współobecności i na skutek współobecności. Jej podstawowymi elementami są spojrzenia, gesty, wypowiedzi wprowadzane świadomie lub nieświadomie przez ludzi do interakcji. Są to pewne zewnętrzne znaki zaangażowania, zarówno umysłu, jak i ciała. Współobecność innych ludzi przekształca każdą ludzką działalność w występ. Istotne staje się nie tylko to, co jednostka robi oraz czy prawidłowo wykonuje swoje zadania (tj. spełnia wymogi systemu, pozycji i roli społecznej), ale przede wszystkim to, czy potrafi wywrzeć odpowiednie wrażenie na obserwatorach (partnerach interakcji) oraz narzucić im swoją wizję sytuacji.

Głównym założeniem podejścia dramaturgicznego jest to, że człowiek w interakcjach z innymi ludźmi prezentuje się im na wzór gry aktorskiej w te- 
atrze (na scenie). Stosując bezpośrednią analogię między życiem społecznym a teatrem, Goffman wyłonił różne techniki zarządzania wrażeniami przez ludzi i instytucje w ich codziennych działaniach. Celem tych zabiegów jest doprowadzenie do wywołania zamierzonego efektu. Ich adresatem jest partner interakcjibędący jednocześnie innym aktorem - a z perspektywy „głównego nadawcy” - publicznością. To właśnie ta teatralno-sceniczna analogia powoduje, że podstawowymi pojęciami, jakimi operuje Goffman, są teatr, scena, występ, zespół (teatralny), publiczność, aktorzy, klakierzy, rekwizyty, kulisy i inne.

Punktem wyjścia dla dalszych analiz jest praca skazanych nad wizerunkiem w grupie współosadzonych, której cel sprowadzał się do pozyskania pożądanej pozycji społecznej (Szczepanik 2015). „Zwycięzca” to osoba, która potrafi skutecznie zakamuflować swój lęk i poczucie osamotnienia, a co więcej: przeobrazić te niepożądane wśród przestępców emocje na złość. To również osoba, stosująca określone taktyki autoprezentacji, służące podtrzymaniu osiągniętej pozycji w grupie (Yewkes 2005; Crewe 2007; Crewe et al., 2014; Szczepanik 2015), szczególnie takiej, która jest wolna od opresji i przemocy ze strony innych (Szczepanik 2015).

Zgodnie z założeniem modelu dramaturgicznego działania autoprezentacyjne podejmowane są wśród współobecnych, i to właśnie dlatego przedmiotem zainteresowania analiz prezentowanych $\mathrm{w}$ artykule nie jest to, co się dzieje między kobietą a mężczyzną, ale między mężczyzną a innymi mężczyznami (współosadzonymi). Kobieta pełni tu jedynie rolę aktora pomocniczego i statysty w przebiegu kreowania wizerunku mężczyzny jako osoby, która - mimo ograniczeń narzucanych przez izolację społeczną - kontroluje i wpływa na wydarzenia przebiegające poza zakładem karnym (także na jej życie intymne). $\mathrm{W}$ przebiegu autoprezentacji recydywisty (i w procesie komunikacji między współosadzonymi), kobieta realizuje swoją rolę według napisanego przez niego scenariusza. Rezultat spektaklu jest bowiem zaplanowany i przewidziany: zarządzanie relacją z kobietą to specyficzny spektakl, który wraz ze swoją dynamiką i dramaturgią składa się na proces (wy)kreowania pożądanego wizerunku w oczach publiczności, jaką są współosadzeni.

Stanowią oni publiczność, będąc nie tylko biernym obserwatorem, ale również zaangażowanym widzem. Jest to bowiem widownia, która kibicuje, dopinguje, doradza i sugeruje akceptowany zwrot akcji danego spektaklu.

Za potraktowaniem relacji recydywistów z kobietami jako swoistej sceny, na której osadzeni dokonują autoprezentacji przed współosadzonymi, przemawia wiele argumentów. W zmaskulinizowanym i hołdującym patriarchalnym wartościom świecie zakładów karnych (m. in. Jewkes 2005; Kamiński 2006) 
związki z kobietami - ich jakość i przebieg - stanowią treść codziennych rozmów, analiz współwięźniów, są przedmiotem insynuacji, zazdrości, a także mogą być poważną przyczyną utraty reputacji przestępcy (jako mężczyzny) w oczach kolegów. Rekonstruowane są wówczas rozmowy telefoniczne, odczytywane fragmenty listów czy relacjonowany jest przebieg widzeń (Kamiński 2006; Miszewski 2004; 2005).

\section{Relacje mężczyzn odbywających karę pozbawienia wolności z partnerkami życiowymi}

Relacje osób odbywających karę pozbawienia wolności z rodziną stanowią często podejmowany przez badaczy przedmiot analiz. Podkreśla się w nich ogromne znaczenie więzi skazanego $\mathrm{z}$ rodziną prokreacji w prognozie resocjalizacyjnej i kryminologicznej (np. Linowski 2005; Machel 2012; Sarzała 2013), a także stworzenie (lub zrekonstruowanie) związku partnerskiego uważane jest za istotny punkt wyjścia dla pozytywnych zmian w zachowaniu skazanego oraz przyczynę świadomego dążenia do udziału w programach resocjalizacyjnych oferowanych przez zakład karny (Adamowska i Kowalczyk 2014; Szczepanik 2015). Wsparcie „Z wolności” ze strony bliskich obniża negatywne emocje osób skazanych oraz sprzyja dystansowaniu się przez nich wobec podkultury więziennej (np. Linowski 2005; Sarzała 2013; Szczepanik 2015).

Ponieważ jakość i siła relacji osoby skazanej z bliskimi analizowana jest jako ważny czynnik sprzyjający konstruktywnemu radzeniu sobie z izolacją więzienną, to między innymi dlatego jednostki penitencjarne stwarzają przestrzeń dla podtrzymywania przez skazanych silnych relacji z rodziną oraz oferują coraz bogatszy system komunikacji sprzyjający utrwalaniu więzi z osobami bliskimi (np. siłę tradycyjnej korespondencji zastąpiły stopniowo połączenia telefoniczne, a także wykorzystywane jest w zakładach karnych oprogramowanie Skype).

Truizmem jest stwierdzenie, że pobyt w zakładzie karnym zmienia pozycję społeczną osoby skazanej w rodzinie, a także znacząco ogranicza możliwości wpływania na przebieg wydarzeń będących udziałem osób bliskich na wolności. Zwłaszcza skazanym na długoterminową karę pozbawienia wolności towarzyszy lęk przed odrzuceniem przez bliskich (Szczepanik, Miszewski 2016) oraz niepewność co do przyszłości związków matrymonialnych, stworzonych przed rozpoczęciem odbywania kary. Obawy te wzmacniane są przez ograniczenia fizyczne (izolację więzienną) oraz przez współosadzonych (ich doświadczenia czy insynuacje). 
Ambiwalentna postawa osadzonych recydywistów wobec kobiet opiera się o przekonanie (i doświadczenia), że kobieta może okazać się jego największą pomocą $\mathrm{w}$ trudnym okresie pobytu w więzieniu albo zadać największy cios: w postaci zdrady i porzucenia (Kamiński 2006). Więzienne kategorie oceny kobiet są bezwzględne - kobiety to matki i siostry, które są „niezmordowanymi dostarczycielkami paczek żywnościowych i pieniędzy na wypiskę" (s. 206-207; por. Miszewski 2005) oraz niewierne lub potencjalnie niewierne partnerki życiowe, wystawione na długoletnią próbę separacji z powodu uwięzienia mężczyzny,nie potrafiące sprostać temu wyzwaniu (Szczepanik 2015).

Zwłaszcza ci recydywiści, którzy podejmują próby zerwania z przestępczym stylem życia dzielą kobiety na pochodzące ze „środowiska” (przestępczego) oraz te, które są przedstawicielkami świata „normalsów”. Pierwsze sprzyjają rozwojowi „kariery dewiacyjnej” i - co się z nią wiąże - powrotowi do więzienia. Znajomości i relacjom z drugimi przypisywane są wysokie czynniki prewencyjne: stoją one na straży pokus przestępcy i stanowią alternatywne (w stosunku do dewiacyjnego) środowisko wsparcia oraz zaspokajania potrzeb psychospołecznych skazanego. Niestety to, co w trakcie więzienia i starań na rzecz przedterminowego uwolnienia stanowi atut $\mathrm{w}$ relacji z kobietą - przedstawicielką świata „normalsów” - po jego opuszczeniu staje się balastem dla tych, którzy porzucają plany życia bez aktywności dewiacyjnej. Kobieta kontroluje zachowania partnera, egzekwuje zasady, deprecjonuje i zabrania podejmowania relacji towarzyskich z dewiacyjnymi kolegami itp. Zostaje w końcu przez niego porzucona lub może stać się jego „zakładniczką”. W tym drugim przypadku mężczyzna może rościć sobie szczególne prawa do jej bezwzględnej lojalności i oddania z powodu wspólnego posiadania dzieci albo też partnerka życiowa zostaje uwikłana $\mathrm{w}$ środowisko przestępcze z powodu doświadczeń przemocy (Szczepanik 2015).

Znaczenie kobiet w życiu notorycznych przestępców jest wielorakie, a ich rola wieloznaczna. Relacje z kobietami są dynamiczne i zmieniają się w zależności od etapu kariery dewiacyjnej realizowanej przez mężczyzn i w trakcie jego pobytu w więzieniu (Ferraro i in. 1983; Fishman 1990; Codd 2003; Comfort $i$ in. 2005; Apel i in. 2010; Condry 2013; Szczepanik 2015).

\section{"Hej zgredy, korniszony..."}

Na jakość relacji skazanych mężczyzn z kobietami często rzutuje strach, u podstaw którego leży niemożność kontrolowania zachowania partnerki poza murami więzienia oraz głęboki i realny niepokój związany z tym, że zostaną oni 
porzuceni przez nie na rzecz innego mężczyzny (Apel et al., 2010). Ten rodzaj lęku wywołuje złość i pogardę, która czasem zamienia się poczucie winy, a następnie w uczucie namiętności i pożądania oraz co się z tym wiąże - tendencją idealizowania wizerunku kobiety. Ambiwalentny stosunek uczuciowy wobec kobiet potęgują mity i rozmowy z innymi więźniami, oraz stawanie się obiektem realnych lub wyimaginowanych drwin ze strony zwłaszcza ,starszych stażem” współosadzonych. Trafnie ilustruje to zjawisko M. Kamiński (2006, s. 207), socjolog mający doświadczenie izolacji więziennej, przywołując następujący zwrot formułowany przez mężczyzn pod adresem nowoprzybyłych: „Hej, zgredy, korniszony. Kto p...li wasze żony?!”.

Ironiczne komentarze słowne, żarty czy pogardliwe porównania kierowane pod adresem kobiety danego więźnia są intencjonalnym aktem, którego celem jest ośmieszanie, nadwerężenie jego reputacji i wizerunku. $Z$ pozoru niewinne działania nadawcy (rozśmieszenie publiczności, dostarczenie rozrywki i przerwanie monotonii więziennej) to $\mathrm{w}$ istocie określona taktyka, której celem jest budowanie lub podtrzymywanie rozkładu pozycji i sił $\mathrm{w}$ grupie: jak poradzi sobie z tym adresat/ofiara insynuacji? Jaką strategię działań nastawionych na unikanie degradacji w grupie zastosuje? Czy zachowa twarz? A jeśli ją utraci, to w jaki sposób będzie próbował ją odzyskać? (szerzej: Szczepanik 2015):

Śmieli się, że przez tyle czasu to tak i tak moja żona kogoś do siebie przygarnie, nawet nie będę wiedział o tym.[fragment wywiadu]

(...) Tak runęła moja duma taka, nie? Która y była taka więzienna, no...y jak w więzieniu, nie? Bo to bądźmy szczerzy, nie chodziło tutaj o żadne uczucia do Beaty, nie? Tylko tą dumę i wstyd wśród kolegów, nie? [fragment wywiadu]

W badaniach własnych perspektywa patriarchalna postrzegania relacji, jakie łączą recydywistów z kobietami najsilniej zaznacza się w wyłonionych strategiach działań, związanych z pokonywaniem warunków nadwyrężających lub stwarzających poważne ryzyko utraty reputacji recydywisty jako mężczyzny, tj. kogoś, kto panuje w związku (i nad nim), nie pozwala się zdradzać i nie jest ofiarą kobiety, potrafi wyegzekwować wierność partnerki, a także kogoś, kto w sytuacji zdrady i nielojalności odzyska swój honor, na przykład w akcie zemsty.

I on wie co się stanie jak ja wyjdę z więzienia (...). Ja nie wiem proszę panią jak ja zareaguję jak tam pójdę i yy no i on otworzy mi drzwi. To mi tu koledzy z mo- 
jej celi mówią - „ty uważaj...a bo jak ci nerwy puszczą i go zadźgasz to wrócisz tutaj do więzienia i będziesz gnił do końca swoich dni i czy warto". [fragment wywiadu].

Działania recydywistów oparte o szeroką kalkulację zysków i strat nastawione są na budowanie i potwierdzanie obrazu kogoś, kto nie tylko jest sprawczy w relacjach z kobietami, ale także jest osobą, która kontroluje i autonomicznie zarządza swoją biografią, nie jest bezwolną marionetką w czyichś rękach.

Specyficzną cechą tych działań jest spektakularność oraz swoiście teatralny rozmach. Są to niezwykle efektowne i dynamiczne w swojej ekspresji taktyki, przebiegające w toku interakcji ze współosadzonymi (widownią lub zaangażowaną publicznością).

\section{„Nie czekaj na mnie"}

Najsilniej wyłonioną taktyką jest przyzwalanie, u której leży silna ambiwalencja motywów działania recydywisty. Recydywista podejmuje szereg zabiegów, których celem jest zainicjowanie i realizacja decyzji o zerwaniu relacji. Ambiwalencja towarzysząca tej taktyce polega na tym, że osobą porzucaną jest kobieta, która stanowi realne wsparcie dla mężczyzny przebywającego w więzieniu i/lub z którą łączy go uczucie. Przyzwalanie może obejmować porzucenie kobiety lojalnej lub kobiety nielojalnej. W pierwszym przypadku taktyka ta polega na tym, że recydywista zrywa z nią relacje mimo braku obiektywnych przesłanek o kryzysie związku. Jest to specyficzne, prewencyjne zakończenie związku i ma na celu budowanie wizerunku mężczyzny, którego się nie zdradza. W drugim jego działania nastawione są na odzyskiwanie „dobrego imienia" i ratowanie „męskiego honoru”.

W przypadku porzucenia kobiety lojalnej recydywista decyduje się na wybór „mniejszego zła” - woli samotność niż ryzyko zdrady. Mężczyzna jest często mocno związany emocjonalnie z kobietą, jednakże lęk przed byciem ofiarą jej niewierności jest silniejszy. Ochrona reputacji i troska o wytwarzanie wizerunku osoby, która kontroluje i panuje nad życiem intymnym swojej kobiety staje się dla niego ważniejsza niż uczucie, jakie do niej żywi.

Obiecywała mi, baaaa, że będzie na mnie czekać. Ale ja i tak i tak wątpiłem. Powiedziałem jej, że „nie czekaj na mnie. Ja i tak i tak już mam kogoś innego. Rób co chcesz. Mnie to już nie będzie obchodzić”. [badania własne, fragment wywiadu] 
Kamiński (2007, s. 207) będąc bezpośrednim obserwatorem tego typu działania pisze o tym następująco: „(...) przewidując, że wcześniej czy później ich kobieta i tak pójdzie w tango, niektórzy sami oferują rozwód, zaraz po aresztowaniu i ochłonięciu z pierwszych emocji. Często później żałują swojej wspaniałomyślności”. Problem ten odnalazłam również w materiale empirycznym pochodzącym z wywiadów z recydywistami:

Z tamtym wyrokiem wziąłem rozwód po 8 latach (...). Ja miałem przed sobą 4 lata kryminału, a ona była młoda. (...) napisałem do niej list, że już nic do niej nie czuję i że jest wolna (...) Tak po prawdzie, to bardzo to odchorowałem. [badania własne, fragment wywiadu]

Recydywistą kieruje lęk przed potencjalną zdradą i porzuceniem, dlatego uprzedza potencjalnie możliwy rozwój niekorzystnych dla niego wydarzeń, eliminując $\mathrm{w}$ ten sposób insynuacje dotyczące niewierności kobiety (w końcu to on ją porzucił i już z nią nie jest):

Ogłosiłem kolegom z celi, że z dniem dzisiejszym już nie jestem z Anką. I że dałem jej wolną rękę. [badania własne, fragment wywiadu]

Akcja rozgrywa się podczas rozmów ze współosadzonymi oraz w przebiegu bezpośredniej interakcji z kobietami, jednakże w istocie jest to jedna scena i jedna publiczność. „Scenografię” spektaklu stanowi specyficzna komunikacja wszystkich uczestników przedsięwzięcia, a rekwizytami są listy oraz rozmowy (telefoniczne lub podczas widzeń, które są odpowiednio rekonstruowane podstawowej publiczności, jaką stanowią współosadzeni). Podstawą dla tak odgrywanej roli „porzucającego”, jest odpowiednio zaprezentowana przy udziale współosadzonych wyidealizowana wizja mężczyzny w życiu kobiety. Odwoływanie się do patriarchalnego systemu wartości oznacza narzucanie relacjom z kobietą tradycyjnego podziału ról społecznych: w związku jest ktoś, kto się opiekuje i zapewnia byt (mężczyzna) i ktoś, kto oczekuje i poddaje się tej opiece (kobieta). Scenerią kulturową dla tak wyreżyserowanej przez recydywistę akcji jest ostentacyjne demonstrowanie przez niego wyznawanych wartości należytego wypełniania męskich powinności i zobowiązań. Prawo do wierności i lojalności posiada więc tylko ten, kto jest w stanie urzeczywistniać te wartości. Pobyt w więzieniu, zwłaszcza długoterminowa kara pozbawienia wolności w sposób naturalny uniemożliwia ich realizację, dlatego mężczyzna daje przyzwolenie kobiecie, by znalazła sobie innego partnera: 
Wzbraniała się przed moja decyzją. Płakała i w ogóle (...) Napisałem jej w końcu w liście tak yy: ,nie chcę ci komplikować życia przeze mnie. Zachowaj po mnie dobre yy wspomnienie i ożeń się z innym mężczyzną" [badania własne, fragment wywiadu]

Nieco inaczej przyzwalanie wygląda w sytuacji, w której doszło do poważnego uszczerbku reputacji recydywisty, ponieważ kobieta z którą był związany sama odeszła lub co gorsze, weszła w związek z innym mężczyzną. Porzuceniu kobiety nielojalnej przez recydywistę towarzyszy demonstracyjne racjonalizowanie jej decyzji i przekonywanie otoczenia, że to on sam do tego doprowadził swoim zachowaniem i nie dał wyboru partnerce. Recydywista znowu sięga do pakietu wartości patriarchalnych i wyciąga z niego argumenty neutralizujące niekorzystne wrażenie: to naturalne, że kobieta nie może być sama i nie potrafi być niezależna; zawsze musi mieć przy swoim boku kogoś, kto się nią zaopiekuje. Uzasadnienie to jest szczególnie przekonujące, gdy wielokrotnie skazany ma dzieci pochodzące ze związku z tą kobietą:

I mój kolega do mnie powiedział kiedyś coś mądrego: „obowiązkiem faceta” mówi - jest być przy kobiecie, a ciebie tam nie ma!” No i ja po tym zdaniu gdzieś to wyłowiłem, no rzeczywiście ja nie zapewniam jej nic!(...) to czy ja mogę mieć pretensje, że ona się chce z kimś związać na stałe? [badania własne, fragment wywiadu]

Ja to tak rozumiem, że ona jest z nim (...) Ona ma trójkę dzieci. Ze mną. (...) Po prostu ona wsparcia nie ma w nikim, to on jej to zapewnia. [fragment wywiadu]

W taktykę przyzwalania wpisuje się również uzasadnianie zdrady kobiety poprzez nadawanie jej znaczenia konsekwencji porzucenia przez recydywistę. Sytuuje więc go w roli sprawcy, a nie ofiary. Odgrywa rolę mężczyzny, który zmusił kobietę do nielojalności, ponieważ ją ,"porzucił” (poprzez trafienie do więzienia na wiele lat), zachował się nie fair (np. nie zabezpieczył jej warunków materialnych na czas pobytu w więzieniu, złamał obietnice poprawy). Dlatego też mężczyzna nadaje jej szczególne prawo do zdrady:

Jeszcze dalej jak jeszcze z kimś rozmawiam, mówię: Dorota, moja moja moja", że wiem, że jak wyjdę na wolność nie odpuszczę, wie pani. Ja sobie nie wyobrażam życia bez niej. Ja muszę jej wybaczyć (...) chodzi mi o tą kwestię, że ona sobie znalazła mężczyznę, po prostu wsparcia nie miała kobieta. Ja nie poszedłem 
siedzieć na chwilę, nie? Ja nie zostawiłem jej y nie wiadomo czego. [badania własne, fragment wywiadu]

\section{„I że gryzę rękę, która mnie karmi"}

Najbardziej spektakularnym i z pozoru nieracjonalnym dla obserwatorów działaniem skazanego jest ostentacyjne zakończenie małżeństwa (poprzez rozwód zainicjowany przez recydywistę), które nosi znamiona wyjątkowo udanego $\mathrm{i}$ istnieje realna szansa na dalsze utrzymanie go mimo wieloletniego nawet pobytu mężczyzny w więzieniu. Taktyka zerwania jest działaniem mężczyzny nastawionym na potwierdzanie i wzmacnianie wizerunku kogoś, kto pozostaje nieugięty i potrafi wiele stracić, aby zachować dumę. Zdaje się także na tyle silny, by ponosić wysokie koszty swojego uporu i nieustępliwości. Stanowi to formę autoprezentacji osoby, która nie negocjuje z kobietą, ale narzuca swoje zdanie i obliguje partnerkę do bezwzględnego podporządkowania się.

Istotne jest to, że decyzja recydywisty o rozwodzie nie zostaje poprzedzona trwającym w czasie kryzysem małżeństwa. Analiza materiału empirycznego pozwala sądzić, że bezpośrednim powodem uruchamiającym specyficzną reakcję łańcuchową są błahe, nieznaczące wydarzenia (np. kobieta nie dołączyła do paczki żądanego produktu albo dostarczyła jego zamiennik) lub niepomyślnie przebiegające sytuacje, mające miejsce na wolności, w których recydywista nie może uczestniczyć i do których deleguje partnerkę życiową (np. nieskuteczne załatwienie przez żonę sporu sąsiedzkiego dotyczącego rezerwacji miejsca parkingowego na podwórku).

Podobnie jak przy wcześniej omawianych działaniach towarzyszących taktyce porzucania kobiety lojalnej, także i w przypadku przebiegu zerwania polegającego na ostentacyjnym zakończenia związku, który nosi znamiona wyjątkowo udanego, ważną rolę pełnią określone rekwizyty (listy, rozmowy telefoniczne) oraz dyskusje z kolegami. Dodatkowego rozmachu działaniom recydywisty dodaje natomiast to, że akcja rozgrywa się na sali sądowej i z zaangażowaniem pełnomocników, prawników oraz dorosłych już dzieci. Konsekwencje działań recydywisty są często bardzo dla niego dotkliwe, a koszty dalekosiężne,obejmując poważne straty rodzinne:

„Ja ci daję wybór, że albo jesteś za mną, albo z matką y przeciwko mnie”. No i co, wybrała. (...) To mnie te słowa gorzko kosztowały, bo przez cały wyrok nie miałem nikogo, żeby mi coś z wolności przyniósł (...), a jak wyszłem, to byłem sam jak pies. Nawet parę razy chciałem zadzwonić do córki i żeby naprawić to co 
się popsuło między nami, ale honor więzienny mi nie pozwalał. [badania własne, fragment wywiadu]

Recydywista wikła się w sprawy sądowe, angażuje prawników, podejmuje nieracjonalne decyzje na rzecz spraw majątkowych. W toku komunikacji ze współosadzonymi, rekonstrukcje przebiegu wywołanej przez niego kłótni i sporu z żoną wypełniają jego więzienne życie. W oczach obserwatorów jego działania - aczkolwiek nieracjonalne i niezachowawcze - świadczą o jego wyjątkowej desperacji. Upór dla stosującego tę taktykę jest oznaką braku słabości i nieustępliwości:

(...) w sumie dwadzieścia, po 22 latach małżeństwa, no to tak z dnia na dzień, ale później to...w sądzie nas chcieli godzić i żałowałem tego w sądzie, ale... już duma mi nie pozwoliła na wycofanie się (...). Znaczy ona mi powiedziała, jak mnie prowadzili na tą sprawę rozwodową, że w życiu mi nie wybaczy. I od tej pory się z nią nie widziałem na oczy. To yy powód podałem, że mam nową kobietę, że z nią chcę sobie ułożyć życie... co było nieprawdą. [badania własne, fragment wywiadu]

Powiedziałem do personelu: ,ja sobie nie życzę odwiedzin mojej żony y tej pani!” (...) Przez głupią zaczepkę z mojej strony wobec żony doprowadziłem do tego, że dorosły syn nie chce mnie znać za to co zrobiłem żonie, że ją porzuciłem będąc we więzieniu i że teraz on się musiał nią zająć. [badania własne, fragment wywiadu]

Często mężczyźni zdają sobie sprawę ze swojej nieracjonalności i nieodwracalnych strat, jakie są konsekwencją ich działań:

Jak szłem na sprawę rozwodową, to wychowawca się nawet dziwił, i że yyy gryzę rękę, która mnie karmi. Tak powiedział i miał rację, ale odwrotu już nie miałem. Nie mogłem. [badania własne, fragment wywiadu]

Aktorami pomocniczymi tej taktyki są koledzy, którzy kierowani troską o kolegę próbują ukazać mu jego nieracjonalne wybory, które są dla niego destrukcyjne. I to oni - dyskusje z nimi i komentarze - są zasadniczym elementem pożądanego efektu „działania” tej strategii. Opór recydywisty pozwala mu bowiem ostatecznie na wzmocnienie budowanego wizerunku osoby nieugiętej, twardej i niezależnej od otoczenia:

Kolega mi mówił coś takiego: „coś ty Mariusz, odpuść. Ona jest dobrą kobietą, niejeden chciałby, że taka żona stała za nim, jak ta twoja”. Ale ja mówię nie 
i już (...). Im bardziej mnie namawiali, żebym jej wybaczył, tym bardziej ja byłem uparty na „nie”. [badania własne, fragment wywiadu]

\section{„Przez ciebie nie mogę sobie ułożyć życia”}

Specyficznym rodzajem prezentowania przed otoczeniem swojego sprawstwa w sytuacji uwięzienia jest uwalnianie partnerek ze związków. Głównymi bohaterami tego spektaklu są ci recydywiści, których negatywny wizerunek jest głęboko zakorzeniony w lokalnej społeczności (miejscu zamieszkania partnerki) i wywołuje lęk. Wysoka i ugruntowana pozycja mężczyzny w środowisku przestępczym naznacza negatywnie jego dzieci i partnerkę życiową nawet, jeśli nie pozostaje ona $z$ nim już $w$ formalnej relacji. W obliczu jej szans na nowy związek pojawia się przeszkoda właśnie w postaci negatywnych uprzedzeń otoczenia wobec nie tyle jej przeszłości, ile związku z recydywistą i lęku przed jego reakcją. W przebiegu uwalniania aktorami pomocniczymi (obok byłej partnerki) są jej potencjalni, nowi towarzysze życiowi i ich rodziny.

Beata nie mogła sobie znaleźć faceta, bo ja w swojej miejscowości mam taką a nie inną opinię i kiedy znalazła sobie chłopaka, to przyjeżdżała do mnie na widzenia i ... mówi: „przez ciebie nie mogę sobie ułożyć życia” (...) poznała chłopaka ze wsi i mówi: „proszę cię" - przyjechała do mnie i mówi: „Marek błagam cię (...) napisz list, że pozwalasz na to, żeby on się ze mną chajtnął". [badania własne, fragment wywiadu]

Stosowaną scenerię w tym swoistym spektaklu splotu interakcji tworzy „teatr cieni". Recydywista skazany jest co prawda na wiele lat pozbawienia wolności, ale wizja jego powrotu do społeczności (acz odległa w czasie) jest niemniej realna, a perspektywa możliwych wydarzeń będących jego udziałem - niepokojąca. Otoczenie boi się, że osadzony dokona zemsty - osobiście lub z pozycji więźnia, za pomocą wspólników ze środowiska przestępczego. Odbywa się więc spektakularne włączanie recydywisty w realizację planów życiowych jego byłej partnerki, a nawet nadawanie mu roli ostatecznego decydenta. Mężczyzna zezwala na zawarcie przez kobietę nowego związku, a czasem narzuca pewne warunki dla powodzenia tego projektu. Wzmacnia to jego wizerunek osoby, „która się liczy" w środowisku (nie tylko przestępczym), którego zdanie należy szanować..

Napisałem to mu [nowemu partnerowi kobiety] - „nie będę nachodził, daję ci słowo, tylko, żebyś się dziećmi zajął". [badania własne, fragment wywiadu] 


\section{Podsumowanie}

W instytucji totalnej człowiek ma bardzo ograniczone możliwości zarządzania swoim życiem oraz uczestniczenia i wpływania na egzystencję członków swojej rodziny. Skazani stosują różne taktyki podtrzymywania więzi z najbliższymi, doprowadzając często do tego, że członkowie rodziny stają się „,współuwięzionymi”, a ich codzienne życie przesycone jest rytmem życia jednostki penitencjarnej (np. oczekiwanie na telefon od męża w określonych godzinach, śledzenie i przestrzeganie procedur dotyczących możliwości dostarczania paczek żywnościowych, spędzanie wielu godzin w poczekalni przywięziennej w oczekiwaniu na odwiedziny) (szerzej: Szczepanik, Miszewski 2016). W niniejszym opracowaniu zainteresowaniem objęłam jednak nie techniki pielęgnowania i podtrzymywania przez skazanych relacji z bliskimi, ale te, które nastawione są na ich zakończenie.

Język opisu uwarunkowań, przebiegu i konsekwencji zerwania relacji z bliskimi kobietami zaczerpnęłam z Goffmanowskiej koncepcji dramaturgicznej. To dlatego, mimo że analizie zostały poddane relacje mężczyzn pozbawionych wolności z kobietami, to potraktowałam je jedynie jako specyficzną przestrzeń (scenę) dla ich pracy nad wizerunkiem w grupie innych mężczyzn przebywających $\mathrm{w}$ więzieniu. Zarządzanie relacjami z kobietami przebiegało bowiem w toku komunikacji z współosadzonymi, którzy byli nierzadko aktorami pomocniczymi, ale przede wszystkim podstawową publicznością działań „zarządzającego”. Określone taktyki postępowania z partnerkami życiowymi (przyzwalanie, zrywanie i uwalnianie) pozwalały recydywistom na budowanie lub odzyskiwanie wizerunku kogoś, kto kontroluje wydarzenia poza więzieniem, autoprezentację osoby niezależnej, sprawczej oraz wzmacnianie reputacji „twardego" i „honorowego" mężczyzny. Rekonstruowany przebieg kłótni, sporów czy spektakularnie przebiegające akty rozstania się z partnerką (właściwieporzucenia jej) miały za zadanie przyciągnąć uwagę współosadzonych (podstawowe audytorium, do którego kierowany był przekaz);zaprezentować przed nimi pożądane oblicze.

Scenariusze tych działań pisane były przez nich z użyciem zespołu idei związanych z aksjologią patriarchalną, a zasadniczym celem było tutaj dostarczanie dowodów publiczności na wyznawanie i urzeczywistnianie przez „porzucających” sztywnej dychotomii tego, co „męskie” i „niemęskie”. W imię ochrony tych wartości recydywiści byli w stanie zrezygnować nawet $\mathrm{z}$ określonych dóbr, które minimalizują dolegliwości izolacji więziennej (wsparcie emocjonalne i materialne, jakiego dostarczają osoby bliskie). 
Odpowiednie zarządzanie relacjami z kobietami przez skazanych sprzyja potwierdzaniu i wzmacnianiu przed otoczeniem wizerunku osoby hołdującej wartościom przestępczym, w których honor i duma (mężczyzny), a także lojalność i wierność (kobiety) pełni ważne miejsce. To między innymi dlatego recydywiści demonstracyjnie porzucają oddane im towarzyszki życiowe podczas odbywania kary pozbawienia wolności, czyli w sytuacji kryzysu życiowego i okresie, kiedy wsparcie osób „z wolności” ma szczególne znaczenie. Podobnie jak Kamiński (2006) traktuję to działanie jako specyficzną reakcję emocjonalną i antycypowanie nielojalnego, niewiernego zachowania kobiety podczas jego pobytu w więzieniu. Przyjęcie modelu dramaturgicznego jako narzędzia analizy działań recydywistów pozwala mi jednak na wysunięcie nieco dalej posuniętego wniosku. Zarządzanie relacjami z kobietami traktuję jako element szerszej strategii budowania przez recydywistę pożądanego wizerunku w grupie współosadzonych i - pośrednio - zdobywania określonej pozycji w środowisku przestępczym. Porzucenie kobiety to jeden ze sposobów na odsunięcie od siebie tych czynników, które w jakikolwiek sposób mogłyby nadwerężyć wizerunek lub obnażyć przed otoczeniem jego słabości. Zerwanie relacji ze wspierającą i oddaną rodziną z powodu błahego incydentu to dostarczenie dowodu na swoją determinację, niezależność i nieustępliwość. Angażowanie się w plany matrymonialne swoich byłych kochanek czy żon, to demonstrowanie siły i autorytetu, jakim obdarza go otoczenie.

Niektóre działania recydywistów w obrębie taktyk zarządzania relacjami z kobietami (i porzucania ich) wydają się nieracjonalne, autodestrukcyjne i przywołują na myśl postępowanie wbrew znanemu przysłowiu o „nie kąsaniu ręki, która karmi”. Inne sprawiają wrażenie wspaniałomyślności i hojności recydywisty wobec kobiety (np. komunikaty typu: ułóż sobie życie, nie czekaj na mnie). W istocie są to intencjonalnie przemyślane działania realizowane według starannie przygotowanego scenariusza, które służą osiąganiu konkretnych korzyści. Owa wspaniałomyślność i troska mężczyzny to zwykle realizacja patriarchalnego systemu wartości, opartego na władzy i podporządkowaniu, a także zniewoleniu i uwalnianiu kogoś z określonych relacji.

\section{Bibliografia}

Ambrozik W. (2013). Totalny, stygmatyzujący i wykluczający charakter oddziaływań resocjalizacyjnych. Resocjalizacja Polska, nr 5, s. 13-21.

Apel R., Blokland A. A., Nieuwbeerta P., van Schellen M. (2010). The Impact of Imprison- 
ment on Marriage and Divorce: A Risk Set Matching Approach. Journal Quantities Criminology, vol. 26, p. 269-300.

Blumer H. (2009). Interakcjonizm symboliczny. Perspektywa i metoda. Kraków: Zakład Wydawniczy Nomos.

Ciosek M. (1995). Człowiek w obliczu izolacji więziennej. Gdańsk: Wydawnictwo „Stella Maris".

Chomczyński P. (2013). Instytucja totalna w obiektywie. Socjologiczna analiza architektury wybranych zakładów karnych. W: T. Ferenc, M. Domański (red.). Architektura przymusu. Interdyscyplinarne studia nad dyscyplinujacymi funkcjami architektury. Łódź: Wyd. Akademii Sztuk Pięknych im. Władysława Strzemińskiego w Łodzi, s. 111-118.

Codd H. (2003). Women inside and out: Prisoners' Partners, Women in prison and the struggle for Identity. Internet Journal of Criminology, p. 1-24.

Comfort M., Grinstead O., McCartney K., Bourgois P., Knight K. (2005). "You can't do nothing in this damn place": Sex and intimacy among couples with an incarcerated male partner. Journal of Sex Research, vol. 42(1), p. 3-12.

Condry R., (2013). Families shamed: The consequences of crime for relatives of serious offenders. Abingdon: Routledge.

Crewe B. (2007). Power, adaptation and resistance in a late-modern men's prison. British Journal of Criminology, vol. 47(2), p. 256-275.

Crewe B., Warr J., Bennett P., Smith A., (2014). The emotional geography of prison life. Theoretical Criminology, vol. 18(1), p. 56-74.

Ferraro K., Johson J. M. Stephen, Jorgensen R., Bolton F.G., (1983). Problems of Prisoners' Families, The Hidden Costs of Imprisonment. Journal of Family Issues, vol. 4(4), p. 575-591.

Fishman L. T. (1990). Women at the wall: A study of prisoners' wives doing time on the outside. Albany: State University of New York Press.

Goffman E. (2008a). Człowiek w teatrze życia codziennego. Warszawa: Wydawnictwo Aletheia.

Goffman E. (2006). Rytuat interakcyjny. Warszawa: Wydawnictwo Naukowe PWN.

Goffman E. (2011). Instytucje totalne. O pacjentach szpitali psychiatrycznych i mieszkańcach innych instytucji totalnych. Sopot: GWP.

Goffman E. (2008b). Zachowanie w miejscach publicznych: o społecznej organizacji zgromadzeń. Warszawa: Wydawnictwo Naukowe PWN.

Hałas E. (2006). Interakcjonizm symboliczny. Społeczny kontekst znaczeń. Warszawa: Wydawnictwo Naukowe PWN. 
Jasińska-Kania A., Nijakowski L., Szacki J., Ziółkowski M. (red.) (2006). Współczesne teorie socjologiczne. Warszawa: Wydawnictwo Naukowe Scholar.

Jewkes Y. (2005). Men Behind Bars: "Doing” Masculinity as an Adaptation to Imprisonment. Men and Masculinities, vol. 8(1), p. 44-63.

Kamiński M. M., (2006). Gry więzienne. Tragikomiczny świat polskiego więzienia. Warszawa: Oficyna Naukowa.

Kowalczyk M., Adamowska O. (2015). Rola związków partnerskich w resocjalizacji i wykonywaniu kary wobec skazanych długoterminowych. Rocznik Andragogiczny, nr 21, s. $237-248$.

Linowski K. (2005). Kontakty skazanych na karę pozbawienia wolności ze światem zewnętrznym. Ostrowiec Świętokrzyski: Wyd. Stowarzyszenie „Nauka, Edukacja, Rozwój”.

Machel H. (2014). Rodzina skazanego jako współuczestnik jego resocjalizacji penitencjarnej, readaptacji i reintegracji społecznej. Resocjalizacja Polska, nr 7, s. 45-57.

Miszewski K. (2004). Grypsera: przemiana, słabnięcie czy upadek subkultury więziennej? (na podstawie obserwacji uczestniczącej $w$ areszcie śledczym $i w$ zakładach karnych), [niepublikowana praca magisterska]. Toruń, Uniwersytet Mikołaja Kopernika.

Miszewski K. (2005). Kobieta złodzieja. Niebieska Linia, nr 5, s. 30-31.

Moczydłowski P. (1988). Drugie życie w instytucji totalnej. Warszawa: IPSiR UW.

Sarzała D. (2013). Patologiczne zachowania więźniów w kontekście izolacji i resocjalizacji

Penitencjarnej. Warszawa: Wydawnictwo ASPRA-IR.

Szczepanik R. (2015). Stawanie się recydywistą. Kariery instytucjonalne osób powracających do przestępczości. Łódź: Wydawnictwo UŁ.

Szczepanik R., Miszewski K. (2016). Wpływ długoterminowego uwięzienia na rodziny więźniów-stan wiedzy i zaniedbane kierunki badań. Profilaktyka Spoleczna i Resocjalizacja, t. 30, s. 53-95.

Wyka A. (1993). Badacz społeczny wobec doświadczenia. Warszawa: Wydawnictwo Instytutu Filozofii i Socjologii PAN. 